\title{
CHEMICAL AND PHYSICAL PROPERTIES OF COMPOST
}

\author{
El-Sayed G. Khater*
}

\begin{abstract}
The objective of this research was to study the chemical and physical properties of compost with different materials. These properties include: $\mathrm{pH}, \mathrm{EC}$, total organic carbon, total organic matter, total nitrogen, total phosphorus, total potassium, $\mathrm{C} / \mathrm{N}$ ratio, bulk density, moisture content, water holding capacity and porosity. The $\mathrm{pH}$ value ranged from 6.3 to 7.8 and EC values ranged from 2.6 to $4.1 \mathrm{dS} \mathrm{m}^{-1}$ for different compost types. The total organic carbon values ranged from 16.6 to $23.89 \%$. The total organic matter values ranged from 28.60 to $41.20 \%$. The total nitrogen values ranged from 0.95 to $1.68 \%$. The total phosphorus and total potassium values ranged from 0.27 to $1.13 \%$ and 0.27 to $2.11 \%$, respectively, for different compost types. The $\mathrm{C} / \mathrm{N}$ ratio values ranged from 14.22:1 to $18.52: 1$. The bulk density value ranged from 420 to 655 $\mathrm{kg} \mathrm{m}^{-3}$. The moisture content values ranged from 23.50 to $32.10 \%$. The water holding capacity values ranged from 3.50 to $4.40 \mathrm{~g}$ water/g dry. The porosity values ranged from 60.69 to $72.47 \%$ for different compost types.
\end{abstract}

Keywords: chemical properties - physical properties - compost

\section{INTRODUCTION}

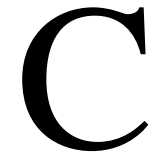
omposting is a technique which can be used to reduce the amount of organic waste through recycling and the production of soil fertilizers and conditioners. Compost is primarily used as a soil conditioner and not as much as a fertilizer because it contains a high organic content (90 - $95 \%$ ) but generally low concentrations of nitrogen, phosphorus, potassium as well as macro and micro nutrients compared to commercial fertilizers. It is comparable to peat moss in its conditioning abilities. Areas where composting can be beneficial is in the recycling of the organic fraction of the municipal waste.

\footnotetext{
*Lecturer, Agricultural Engineering Department, Faculty of Agriculture, Benha University, Egypt - E-mail address: elsayed.khater@fagr.bu.edu.eg
} 
It reduces as much as $30 \%$ of the volume, in the form of organic matter, entering our already overcrowded landfill sites. Furthermore the composting process, if performed correctly, transforms wet and odorous organic waste into an aesthetically, dryer, decomposed and reusable product (Knight, 1997).

Crop residues, unused bedding materials, silage, manures, and similar onfarm materials can be used as co-compost cover materials, along with many off-farm residues and wastes. Since a mortality compost pile cannot be turned until the bio-decomposition of the carcass body has been largely completed, the type and thickness of the cover and base layer materials play a key role in influencing the biodegradation of carcasses, and the development and retention of heat that is necessary for pathogen inactivation (Fonstad et al., 2003).

Quality control during compost production should ensure adequate chemical and physical properties (Inbar et al., 1993), as well as an adequate degree of stability and maturity (Benito et al., 2003). The beneficial effects on crop production and soil quality reported in literature (Hoitink et al., 1997; Atiyeh et al., 2001) are directly related to the physical, chemical and biological properties of the composts (He et al., 1995).

The physical and chemical properties of organic wastes and the factors that affect their performance in composting require easily identifiable and reliable methods to control the process in situ, in order to make proper decisions about its performance (Hurerta-Pujol et al., 2010).

Although the characteristics of yard waste will vary, depending upon the predominant vegetation in the area and the season of the year for its collection, composted green waste typically contains low levels of heavy metals, commonly present in sludge-based composts, which makes them more environmentally sound (Bentio et al., 2006).

To produce a sound and a good quality compost, chemical and physical properties of the compost should be determined by the end of processing period, therefore, the main objective of this research was to study the chemical and physical properties of compost with different materials. These properties include: $\mathrm{pH}, \mathrm{EC}$, total organic carbon, total organic 
matter, total nitrogen, total phosphorus, total potassium, $\mathrm{C} / \mathrm{N}$ ratio, bulk density, moisture content, water holding capacity and porosity.

\section{MATERIALS AND METHODS}

The experiment was carried out at compost unit at Experimental Research Station at the Faculty of agriculture, Moshtohor, Benha University. The raw materials properties that used in the manufacturing the compost are listed in tables (1 and 2).

Five different types of compost were obtained by mixing cattle manure with herbal plants residues and sugar cane plants residues at different ratios to form:

1- $\mathrm{C}_{1}$ : cattle manure $(100: 0)$

2- $\mathrm{C}_{2}$ : cattle manure and herbal plants residues (50:50)

3- $\mathrm{C}_{3}$ : cattle manure and sugar cane plants residues (50:50)

4- $\mathrm{C}_{4}$ : herbal plants residues (100:0)

5- $\mathrm{C}_{5}$ : sugar cane plants residues (100:0)

Table (1): Chemical properties of the raw materials used in compost making.

\begin{tabular}{|l|c|c|c|}
\hline $\begin{array}{l}\text { Raw } \\
\text { materials } \\
\text { Properties }\end{array}$ & $\begin{array}{c}\text { cattle } \\
\text { manure }\end{array}$ & $\begin{array}{c}\text { herbal plants } \\
\text { residues }\end{array}$ & $\begin{array}{c}\text { Sugar cane } \\
\text { plants } \\
\text { residues }\end{array}$ \\
\hline $\mathrm{pH}$ & 8.10 & 4.30 & 7.10 \\
\hline EC $\left(\mathrm{dS} \mathrm{m}{ }^{-1}\right)$ & 4.20 & 1.30 & 3.10 \\
\hline $\begin{array}{l}\text { Total organic carbon } \\
(\%)\end{array}$ & 18.16 & 9.40 & 20.00 \\
\hline $\begin{array}{l}\text { Total organic matter } \\
(\%)\end{array}$ & 31.30 & 43.10 & 61.30 \\
\hline Total nitrogen $(\%)$ & 0.93 & 1.35 & 1.62 \\
\hline Total phosphorus $(\%)$ & 0.21 & 0.36 & 1.12 \\
\hline Total potassium $(\%)$ & 0.17 & 0.42 & 1.36 \\
\hline C/N ratio & $19.53: 1$ & $6.97: 1$ & $12.35: 1$ \\
\hline
\end{tabular}


Table (2): Physical properties of the raw materials used in compost making.

\begin{tabular}{|l|c|c|c||}
\hline \multicolumn{1}{|c|}{ Raw } & $\begin{array}{c}\text { herbal plants } \\
\text { materials } \\
\text { Properties }\end{array}$ & $\begin{array}{c}\text { Sugar cane } \\
\text { manure }\end{array}$ & $\begin{array}{c}\text { residues } \\
\text { plants residues }\end{array}$ \\
\hline $\begin{array}{l}\text { Bulk density }(\mathrm{kg} \\
\left.\mathrm{m}^{-3}\right)\end{array}$ & 750.00 & 335.00 & 426.00 \\
\hline $\begin{array}{l}\text { Moisture content } \\
(\%)\end{array}$ & 58.30 & 16.20 & 36.20 \\
\hline $\begin{array}{l}\text { Water holding } \\
\text { capacity (g } \\
\text { water/g dry } \\
\text { sample) }\end{array}$ & 3.00 & 3.50 & 3.30 \\
\hline Porosity (\%) & 41.57 & 80.62 & 69.96 \\
\hline
\end{tabular}

The mixtures of wastes were composted in trapezoidal piles $(1.5 \mathrm{~m}$ high, $3 \mathrm{~m}$ width and $80 \mathrm{~m}$ long). The piles were turned periodically to maintain adequate $\mathrm{O}_{2}$ levels. The piles were turned weekly during the maturation phase in order to improve the $\mathrm{O}_{2}$ level inside the pile. Pile moisture was controlled by adding enough water to keep the moisture content not less than $50 \%$. Samples were taken at the end of the composting process to determine the chemical and physical properties.

Each sample was made by mixing five subsamples taken from five points in the pile. Samples were placed in polyethylene bags and transferred to the laboratory for analysis.

\section{- Chemical properties:}

Electrical conductivity and $\mathrm{pH}$ were analysed in a 1:5 (v/v) water extract using a glass electrode according to Rayment and Higginson (1992). Total organic carbon (TOC) by the dry combustion method at $540{ }^{\circ} \mathrm{C}$ for $4 \mathrm{~h}$ according to Abad $\boldsymbol{e t}$ al. (2002). Total organic matter was measured by combustion at $550 \circ \mathrm{C}$ for $8 \mathrm{~h}$ according to TMECC (2001) and total nitrogen (TN) by Kjeldahl digestion (Bremmer and Mulvaney, 1982). Potassium (K) was determined by atomic absorption and phosphorus (P) 
was determined colorimetrically following the Murphy and Riley (1962) method.

\section{- Physical properties}

- Moisture contents (MC):

Moisture content (wet basis) throughout this study was measured by drying at $105{ }^{\circ} \mathrm{C}$ for approximately $24 \mathrm{~h}$ or at constant weight.

\section{- Water holding capacity (WHC):}

A wet sample of known initial moisture content was weighed $\left(\mathrm{W}_{\mathrm{i}}\right)$ and placed in a beaker. After soaking in water for 1-2 days and draining excess water through Whatman \#2filter paper, the saturated sample was weighed again $\left(\mathrm{W}_{\mathrm{s}}\right)$. The amount of water retained by dry sample was calculated as the WHC. The water holding capacity (g water/g dry material) is calculated as (Ahn $\boldsymbol{e t}$ al., 2008):

$$
W H C=\frac{\left\{\left(W_{s}-W_{i}\right)+M C \times W_{i}\right\}}{\left\{(1-M C) \times W_{i}\right\}}
$$

Where:

$\mathrm{W}_{\mathrm{i}}$ is the initial weight of sample $(\mathrm{g})$

$\mathrm{W}_{\mathrm{s}}$ is the final weight of sample $(\mathrm{g})$

$\mathrm{MC}$ is the initial moisture content of sample (decimal)

\section{- Bulk density and porosity}

Bulk density was measured using an approximately 10 liter volume container. The container was filled with material, and then the material was slightly compacted to ensure absence of large void spaces. The bulk density was calculated by dividing the weight of the material by the volume of material in the container.

Compost porosity $\left(\varepsilon_{\mathrm{a}}\right)$ was determined using the known density of water $\left(\rho_{\mathrm{w}} ; 1000 \mathrm{~kg} \mathrm{~m}^{-3}\right)$ and estimated densities of organic matter $\left(\rho_{\mathrm{om}} ; 1600 \mathrm{~kg}\right.$ $\left.\mathrm{m}^{-3}\right)$, and ash $\left(\rho_{\text {ash }} ; 2500 \mathrm{~kg} \mathrm{~m}^{-3}\right)$, as well as the moisture content and bulk densities of the sample (Raman, 1995; van Cingel et al., 1999; Richard et al., 2002). If the moisture content (MC), dry matter (DM), organic 
matter $(\mathrm{OM})$, and wet bulk density $\left(\rho_{\mathrm{wb}}\right)$ of samples are known, the porosity can be calculated using the following equation:

$$
\varepsilon_{a}=1-\rho_{w b}\left(\frac{M C}{\rho_{w}}+\frac{D M \cdot O M}{\rho_{o m}}+\frac{D M \cdot(1-O M)}{\rho_{a s h}}\right) \times 100
$$

Where:

$\varepsilon_{\mathrm{a}}$ is the porosity (\%)

$\rho_{\mathrm{wb}}$ is the wet bulk density $\left(\mathrm{kg} \mathrm{m}^{-3}\right)$

$\rho_{\mathrm{w}}$ is the density of water $\left(\mathrm{kg} \mathrm{m}^{-3}\right)$

$\rho_{\mathrm{om}}$ is the density of organic matter $\left(\mathrm{kg} \mathrm{m}^{-3}\right)$

$\rho_{\text {ash }}$ is the density of ash $\left(\mathrm{kg} \mathrm{m}^{-3}\right)$

$\mathrm{MC}$ is the moisture content (decimal)

DM is the dry matter (decimal)

$\mathrm{OM}$ is the organic matter (decimal)

\section{RESULTS AND DISCUSSION}

\section{- Chemical properties:}

Table (3) shows the chemical properties ( $\mathrm{pH}, \mathrm{EC}$, total organic carbon, total organic matter, total nitrogen, total phosphorus, total potassium and $\mathrm{C} / \mathrm{N}$ ratio) of different types of compost (cattle manure, cattle manure and herbal plants residues (50:50), cattle manure and sugar cane plants residues (50:50), herbal plants residues and sugar cane plants residues). It could be seen that the $\mathrm{pH}$ value ranged from 6.3 to 7.8 for different compost types. The highest value of $\mathrm{pH}$ (7.8) was found for herbal plants residues compost, while, the lowest value of $\mathrm{pH}$ (6.3) was obtained for sugar cane plants residues compost. This $\mathrm{pH}$ range is in the optimum range for growing media as mentioned by Bunt (1988) who stated that the optimal range is from 5.2 to 7.3.

The EC values ranged from 2.6 to $4.1 \mathrm{dS} \mathrm{m}^{-1}$ for different compost types. The highest value of EC $\left(4.1 \mathrm{dS} \mathrm{m} \mathrm{m}^{-1}\right)$ was found for cattle manure compost and the lowest value of EC $\left(2.6 \mathrm{dS} \mathrm{m}^{-1}\right)$ was determined for the 
herbal plants residues compost. This EC range is in the optimum range (2.0 to 4.0) for growing media as mentioned by Hanlon (2012).

Table (3): Chemical properties of different compost types.

\begin{tabular}{|l|c|c|c|c|c|}
\hline \multicolumn{1}{|c|}{ Compost } & $\mathrm{C}_{1}$ & $\mathrm{C}_{2}$ & $\mathrm{C}_{3}$ & $\mathrm{C}_{4}$ & $\mathrm{C}_{5}$ \\
\hline $\mathrm{pH}$ & 7.30 & 7.60 & 7.20 & 7.80 & 6.30 \\
\hline $\begin{array}{l}\text { EC }\left(\mathrm{dS} \mathrm{m}^{-1}\right) \\
\text { Total organic carbon } \\
(\%)\end{array}$ & 4.10 & 3.10 & 3.60 & 2.60 & 3.20 \\
\hline $\begin{array}{l}\text { Total organic matter } \\
(\%)\end{array}$ & 28.60 & 32.70 & 35.60 & 36.10 & 41.20 \\
\hline Total nitrogen (\%) & 0.95 & 1.26 & 1.32 & 1.13 & 1.68 \\
\hline $\begin{array}{l}\text { Total phosphorus } \\
(\%)\end{array}$ & 0.31 & 0.27 & 0.51 & 0.32 & 1.13 \\
\hline Total potassium (\%) & 0.27 & 0.35 & 0.62 & 0.51 & 2.11 \\
\hline C/N ratio & 17.47 & 15.06 & 15.64 & 18.52 & 14.22 \\
\hline
\end{tabular}

$\mathrm{C}_{1}$ : cattle manure (100:0) $\mathrm{C}_{2}$ : cattle manure and herbal plants residues (50:50) $\mathrm{C}_{3}$ : cattle manure and sugar cane plants residues (50:50)

$C_{4}$ : herbal plants residues (100:0) $\quad C_{5}$ : sugar cane plants residues (100:0)

Regarding the total organic carbon results it was found that it ranged from 16.6 to $23.89 \%$ for different compost types under study, where, the lowest value of total organic carbon (16.6\%) was found for cattle manure compost and the highest value of total organic carbon (23.89\%) was obtained for sugar cane plants residues compost. These results are in 
agreement with (Batjes., 1996) who found that the optimum value of total organic matter higher than $10 \%$.

The total organic matter values ranged from 28.60 to $41.20 \%$ for different compost types. The lowest value of total organic matter (28.60 $\%$ ) was found for cattle manure compost and the highest value of total organic matter $(41.20 \%)$ was found for sugar cane plants residues compost. These results are in agreement with (Benito et al., 2006) whose found that the highest value of total organic matter about $44 \%$.

The total nitrogen values ranged from 0.95 to $1.68 \%$ for different compost types under study. The lowest value of total organic carbon $(0.95 \%)$ was found for cattle manure compost and the highest value of total organic carbon $(1.68 \%)$ was found for sugar cane plants residues compost. These results are in agreement with those obtained by Benito $\boldsymbol{e t}$ al. (2006) whose found that the total nitrogen rate ranged from 0.99 to $2.01 \%$.

The total phosphorus and total potassium values ranged from 0.27 to 1.13 $\%$ and 0.27 to $2.11 \%$, respectively, for different compost types. The lowest value of total phosphorus $(0.27 \%)$ was found for herbal plants residues and cattle manure (50:50) compost and the highest value of total phosphor $(1.13 \%)$ was found for sugar cane plants residues compost. The lowest value of total potassium $(0.27 \%)$ was found for cattle manure compost and the highest value of total potassium $(2.11 \%)$ was found for sugar cane plants residues compost.

Regarding the $\mathrm{C} / \mathrm{N}$ ratio, it ranged from 14.22:1 to $18.52: 1$ for different compost types. The lowest value of $\mathrm{C} / \mathrm{N}$ ratio (14.22:1) was found for sugar cane plant residues compost and the highest value of $\mathrm{C} / \mathrm{N}$ ratio (18.52:1) was found for herbal plant residues compost. These results are in agreement with the results obtained by (Rosen $\boldsymbol{e t}$ al., 1993) whose found that the $\mathrm{C} / \mathrm{N}$ ratio ranged from $15: 1$ to $20: 1$ is ideal for ready-touse compost.

\section{- Physical properties:}

Table (4) shows the physical properties (bulk density, moisture content, water holding capacity and porosity) of the different types of compost 
(cattle manure, cattle manure and herbal plants residues (50:50), cattle manure and sugar cane plants residues (50:50), herbal plants residues and sugar cane plants residues).

The results indicate that the bulk density value ranged from 420 to 655 $\mathrm{kg} \mathrm{m}^{-3}$ for different compost types. The highest value of bulk density $\left(655 \mathrm{~kg} \mathrm{~m}^{-3}\right)$ was found for cattle manure compost and the lowest value of bulk density ( $420 \mathrm{~kg} \mathrm{~m}^{-3}$ ) was found for sugar cane plants residues compost. Hurerta-Pujol et al. (2010) found that the bulk density values were between 447 and $502 \mathrm{~kg} \mathrm{~m}^{-3}$ for different compost types, as agreed with (Raviv et al., 1986, 1987; Larney et al., 2000; Mohee and Mudhoo, 2005; Romeela et al., 2008) results.

Table (4): Physical properties of different compost types.

\begin{tabular}{|l|c|c|c|c|c|}
\hline \multicolumn{1}{|c|}{ Compost } & $\mathrm{C}_{1}$ & $\mathrm{C}_{2}$ & $\mathrm{C}_{3}$ & $\mathrm{C}_{4}$ & $\mathrm{C}_{5}$ \\
\hline $\begin{array}{l}\text { types } \\
\text { Properties }\end{array}$ & 655.00 & 625.00 & 573.00 & 582.00 & 420.00 \\
\hline $\begin{array}{l}\text { Bulk density }\left(\mathrm{kg} \mathrm{m}^{-}\right. \\
\text {Moisture content } \\
(\%)\end{array}$ & 25.60 & 23.50 & 30.10 & 31.20 & 32.10 \\
\hline $\begin{array}{l}\text { Water holding } \\
\text { capacity (g water/g } \\
\text { dry sample) }\end{array}$ & 3.50 & 3.70 & 4.10 & 3.90 & 4.40 \\
\hline Porosity (\%) & 60.69 & 62.67 & 63.52 & 66.56 & 72.47 \\
\hline
\end{tabular}

$\mathrm{C}_{1}$ : cattle manure (100:0) $\mathrm{C}_{2}$ : cattle manure and herbal plants residues (50:50)

$\mathrm{C}_{3}$ : cattle manure and sugar cane plants residues (50:50)

$\mathrm{C}_{4}$ : herbal plants residues (100:0) $\quad \mathrm{C}_{5}$ : sugar cane plants residues (100:0)

It could be seen that the bulk density of compost decreases with increasing the compost total organic matter. Figure (1) shows the relationship between the bulk density and the total organic matter. It decreases from 655 to $420 \mathrm{~kg} \mathrm{~m}^{-3}$ when the total organic matter increased from 28.6 to $41.2 \%$. 


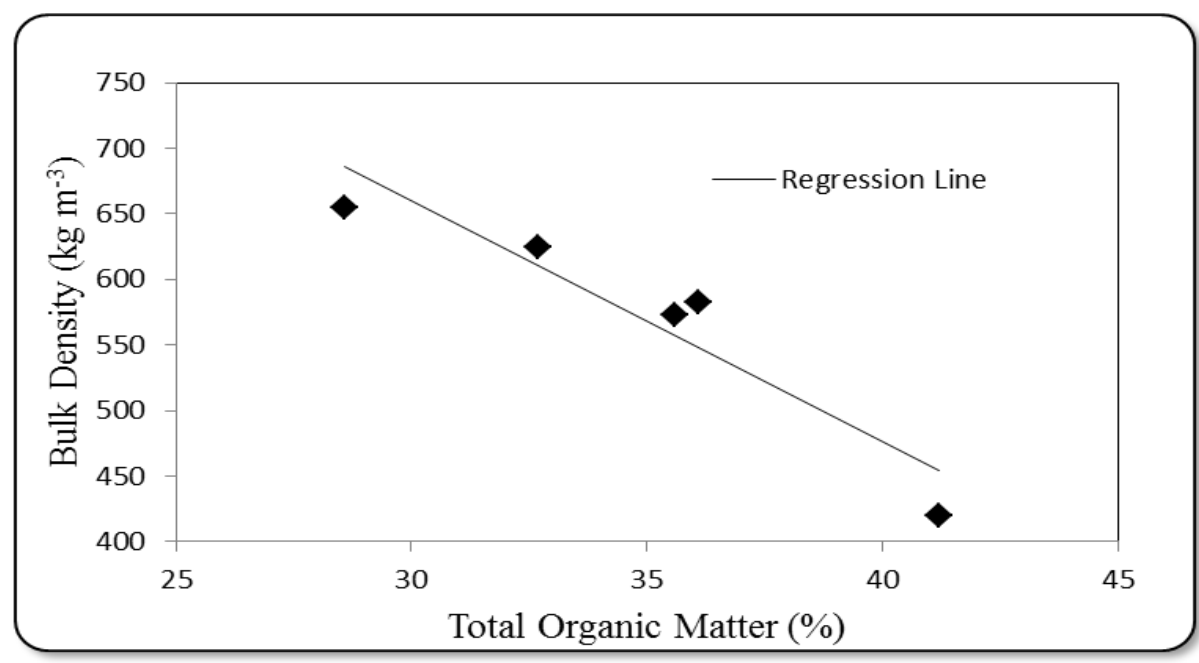

Figure (1): The relationship between the bulk density and the total organic matter.

The regression between the bulk density of compost and the compost total organic matter is show the following equation:

$$
\mathrm{BD}=-18.399 \mathrm{TOM}+1212 \quad \mathrm{R}^{2}=0.89
$$

Where:-

BD is the bulk density $\left(\mathrm{kg} \mathrm{m}^{-3}\right)$

TOM is the total organic matter (\%)

The moisture content values ranged from 23.50 to $32.10 \%$ for different compost types. The lowest value of moisture content $(23.50 \%)$ was found for cattle manure and herbal plants residues (50:50) compost and the highest value of moisture content $(32.10 \%)$ was obtained for sugar cane plants residues compost.

Regarding the water holding capacity values ranged from 3.50 to $4.40 \mathrm{~g}$ water/g dry sample for different compost types. The lowest value of water holding capacity ( $3.50 \mathrm{~g}$ water/g dry sample) was found for cattle manure compost and the highest value of water holding capacity $(4.40 \mathrm{~g}$ water/g dry sample) was found for sugar cane plants residues compost.

The porosity values ranged from 60.69 to $72.47 \%$ for different compost types. The lowest value of the porosity $(60.69 \%)$ was found for cattle manure compost and the highest value of the porosity $(72.47 \%)$ was found for sugar cane plants residues compost. The porosity depends on 
bulk density and moisture content of compost. The porosity decreased with increasing bulk density and moisture content. Figures (2 and 3) show the relationship between the porosity and bulk density and the porosity and moisture content. The results indicate that the porosity of compost decreased from 72.47 to $60.69 \%$ when the bulk density increased from 420 to $655 \mathrm{~kg} \mathrm{~m}^{-3}$. The results indicate that the porosity of compost decreased from 72.47 to $60.69 \%$ when the moisture content increased from 25.6 to $32.1 \%$. This results agreed with those obtained by Ahn et al. (2008).

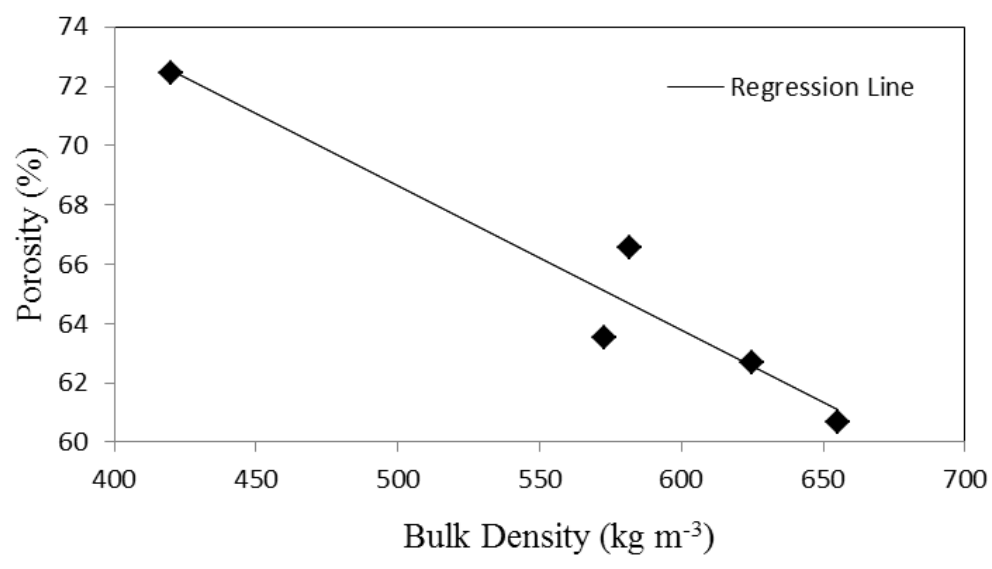

Figure (2): The relationship between the porosity and bulk density.

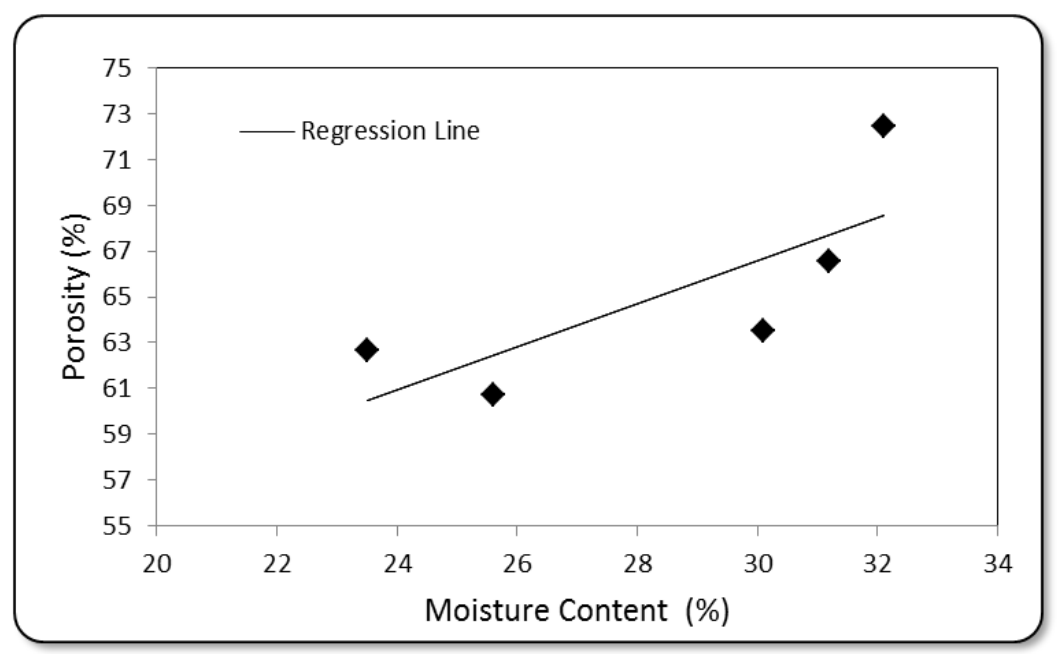

Figure (3): The relationship between the porosity and moisture content. 
The regression between the porosity and the bulk density of compost and the porosity of compost and the compost total organic matter are shown in the following equations:

$$
\begin{aligned}
\varepsilon_{\mathrm{a}}=-0.0487 \mathrm{BD}+92.981 & \mathrm{R}^{2}=0.93 \\
\varepsilon_{\mathrm{a}}=0.9407 \mathrm{TOM}+38.373 & \mathrm{R}^{2}=0.60
\end{aligned}
$$

\section{SUMMARY AND CONCLUSIONS}

An experimental study was carried out successively to determine the chemical and physical properties of different compost types. The obtained results indicate that the $\mathrm{pH}$ value ranged from 6.3 to 7.8 and $\mathrm{EC}$ values ranged from 2.6 to $4.1 \mathrm{dS} \mathrm{m}^{-1}$ for different compost types. The total organic carbon values ranged from 16.6 to $23.89 \%$. The total organic matter values ranged from 28.60 to $41.20 \%$. The total nitrogen values ranged from 0.95 to $1.68 \%$. The total phosphorus and total potassium values ranged from 0.27 to $1.13 \%$ and 0.27 to $2.11 \%$, respectively, for different compost types. The $\mathrm{C} / \mathrm{N}$ ratio values ranged from 14.22:1 to $18.52: 1$. The bulk density value ranged from 420 to 655 $\mathrm{kg} \mathrm{m}^{-3}$. The moisture content values ranged from 23.50 to $32.10 \%$. The water holding capacity values ranged from 3.50 to $4.40 \mathrm{~g}$ water/g dry. The porosity values ranged from 60.69 to $72.47 \%$ for different compost types.

\section{REFERENCES}

Abad, M., P. Noguera, R. Puchades, A. Maquieira and V. Noguera (2002). Physico-chemical and chemical properties of some coconut coir dusts for use as a peat substitute for containerised ornamental plants. Bioresour. Technol. 82: 241 - 245.

Ahn, H. K., T. L. Richard and T. D. Glanville (2008). Laboratory determination of compost physical parameters for modeling of airflow characteristics. Waste Management, 28: 660 - 670. 
Atiyeh, R. M., C. A. Edwards, S. Subler and J. D. Metzger (2001). Pig manure vermicompost as component of a horticultural bedding plant medium: effects on physicochemical properties and plant growth. Bioresour. Technol. 78: 11-20.

Batjes, N. H. (1996). Total carbon and nitrogen in the soils of the world. Eur. J. Soil Sci., 47: 151 - 163.

Benito, M., A. Masaguer, , A. Moliner, and R. De Antonio (2006). Use of pruning waste compost as a component in soilless growing media. Bioresour. Technol. 97: 2071 - 2076.

Benito, M., A. Masaguer, A. Moliner, N. Arrigo and R. M. Palma (2003). Chemical and microbiological parameters for the characterisation of stability and maturity of pruning waste compost. Biol. Fert. Soils 37: 184-189.

Bremmer, J. M. and C. S. Mulvaney (1982). Nitrogen-total. In: Page, A.L., Miller, R.H., Keeney, D.R. (Eds.), Methods of Soil Analysis, Part 2. Chemical and Microbiological Properties, second ed., Agronomy series No. 9 ASA, SSSA, Madison, WI, pp. 595-624.

Bunt, A. C. (1988). Media and Mixes for Container-Grown Plants, second ed. Unwin Hyman Ltd., London, UK.

Fonstad, T. A., D. E. Meier, L. J. Ingram and J. Leonard (2003). Evaluation and demonstration of composting as an option for dead animal management in Saskatchewan. Canadian Biosystems Engineering, 45(6): 19 - 25.

Hanlon, E. A. (2012). Soil pH and electrical conductivity: a count extension soil laboratory manual. http://edis:ifas.ufl.edu.

He, X., T. J. Logan and S. J. Traina (1995). Physical and chemical characteristics of selected US Municipal solid waste composts. J. Environ. Qual. 24: 543 - 552. 
Hoitink, H. A., A. G. Stone and D. Y. Han (1997). Suppression of plant diseases by composts. HortScience 32: $184-187$.

Huerta-Pujol, O., M. Soliva, F. X. Martinez-Farre, J. Valero and M. Lopez (2010). Bulk density determination as a simple and complementary too in composting process control. Bioresour. Technol. 101: 995 - 1001 .

Inbar, Y., Y. Chen and H. A. Hoitink (1993). Properties for establishing standards for utilization of composts in container media. In: Hoitink, H.A.J., Keener, H.M. (Eds.), Science and Engineering of Composting: Design, Environmental. Microbiological and Utilization Aspects. Ohio State University, USA, pp. $668-690$.

Knight, W. (1997). Compost convective airflow, N and C conservation with passive and active aeration. M. Sc. Thesis, Agric. And Biosystems Eng. McGill Univ. Canada.

Larney, F. J., A. F. Olson, A. A. Carcamo and C. Chang (2000). Physical changes during active and passive composting of beef feedlot manure in winter and summer. Bioresour. Technol. 75: 139 -148 .

Mohee, R. and A. Mudhoo (2005). Analysis of the physical properties of an in-vessel composting matrix. Powder Technol. 155: 92 - 99.

Murphy, J. and J. P. Riley (1962). A modified single solution method for determination of phosphate in natural waters. Anal. Chem. Acta 27: $31-36$.

Raman, S., (1995). Food Properties Handbook. CRC Press, Boca Raton, Florida.

Raviv, M., S. Medina, Y. Chen, , Y. Inbar and Z. Geler (1986). Changes in the chemical and horticultural properties during 
composting of slurry produced by methanogenic fermentation of dairy cow manure. In: De Bertoldi, M., Ferranti, M.P., L'Hermite, P., Zuconi, F. (Eds.), Compost: Production Quality and Use. Elsevier Applied Science, London, pp. 377-382.

Raviv, M., S. Tarre, Z. Geler and G. Shelef (1987). Changes in some physical and chemical-properties of fibrous solids from cow manure and digested cow manure during composting. Biol. Waste, 19: $309-318$.

Rayment, G. E. and F. R. Higginson (1992). Australian Laboratory Handbook of Soil and Water Chemical Methods. Inkata Press, Melbourne.

Richard, T. L., H. V. M. Hamelers, A. H. M. Veeken and T. Silva (2002). Moisture relationships in compositng processes. Compost Science and Utilization 10: 286 - 302.

Romeela, M., M. Ackmez and G. D. Unmar (2008). Windrow cocomposting of shredded office paper and broiler litter. Int. J. Environ. Waste Manage. 2: 3-23.

Rosen, C. J., T. R. Halbach and B.T. Swanson (1993). Horticultural uses of municipal solid waste components. Hortic. Technol. 3: 167-173.

Test Methods for the Examination of Composting and Compost (TMECC) (2001).The Composting Council Research and Education Foundation.

van Cingel, C. T., P. A. C. Raats and I. A. van Haneghem (1999). Bulk density and porosity distributions in a compost pile. Netherlands Journal of Agricultural Science 47: 105 - 121. 


\section{الملخص العربي \\ الخصائص الكيميائية والطبيعية للسماد العضوى (الكمبوست) \\ *السبد جمعه خاطر}

نظرا لعدم وجود معلومات كافية عن الخواص الكيميائية والطبيعية للسماد العضوى (الكمبوست)، و لانتاج سماد عضوى ذات صفات جودة عالية يجب در اسة الخصائص الكيميائية و الهندسية فى نهاية دورة الانتاج، ولذلك كان الهدف من هذا البحث هو دراسة الخصائص

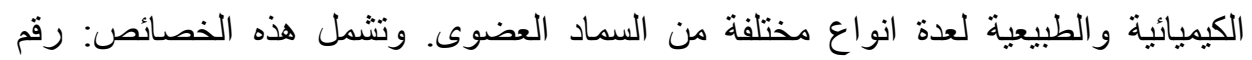
الحموضة و التوصيل الكهربى والكربون العضوى الكلى المادة العضوية الكلية والفوسفور

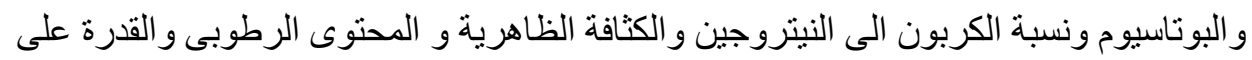
الاحتفاظ بالماء و المسامية.

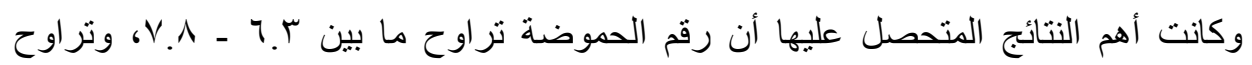

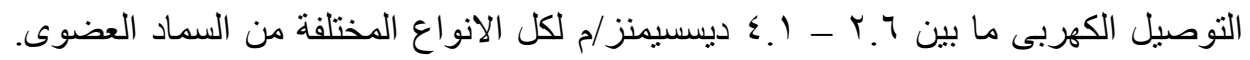

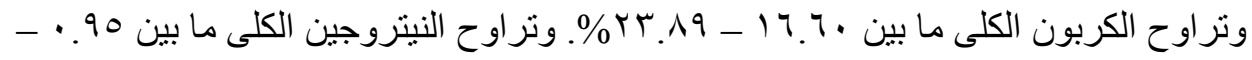

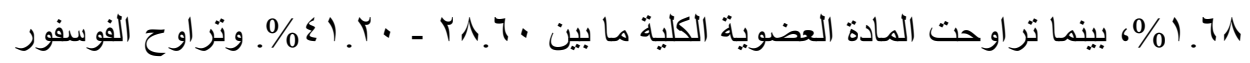

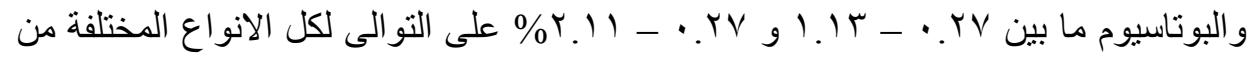

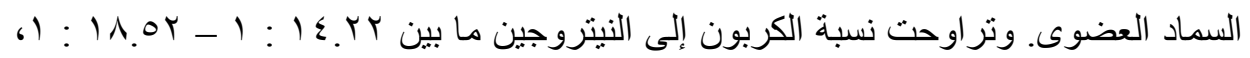

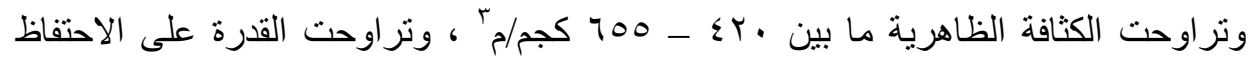

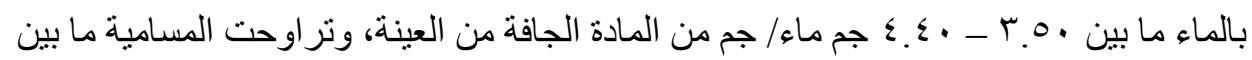

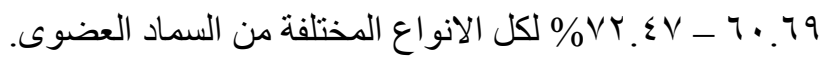

* مدرس الهندسة الزراعية ـ كلية الزراعة بمشتهز - جامعة بنها 